\title{
Problem interpretacji myśli Parmenidesa w duchu monizmu predykatywnego i numerycznego
}

\author{
Alexandre Uchan \\ (Uniwersytet Warszawski, Szkoła Doktorska Nauk Humanistycznych)
}

\section{Wprowadzenie}

Jak zauważa Patricia Curd, dominującą interpretacją myśli Parmenidesa (przynajmniej w świecie anglosaskim, głównie za sprawą prac Owena ${ }^{1}$ jest ta, która za przedmiot rozważań mędrca z Elei uważa jeden jedyny Byt. W związku z tym powszechnie przypisuje się Parmenidesowi pogląd monizmu numerycznego. W opozycji do tej interpretacji Curd proponuje własną egzegezę myśli Eleaty i wychodzi od obserwacji, jakoby interpretacja klasyczna (tj. w duchu monizmu numerycznego) miała stać przed problemem, jakim jest recepcja myśli Parmenidesa przez późniejszych presokratyków. Jej zdaniem to właśnie poglądy takich myślicieli jak Empedokles, Anaksagoras czy atomiści zdają się sugerować, że sam Eleata monistą numerycznym nie był:

W przypadku standardowej interpretacji [tj. interpretacji Owena, w duchu monizmu numerycznego] musimy albo przyjąć, że późniejsi presokratycy nie zrozumieli Parmenidesa, albo stwierdzić, że uznali oni, iż mogą zignorować jego argumentację, akceptując jednocześnie pewne jego tezy o tym, co istnieje² .

1 G.E.L. Owen, Eleatic Questions, w: Logic, Science, and Dialectic, eds. M. Nussbaum, NCROL, London 1986., s. 3-26.

2 P. Curd, The Legacy of Parmenides, Princeton University Press, Princeton 1998, s. 13: „On the standard interpretation we must either attribute serious misunderstanding of Parmenides to 
Jak zostanie wskazane poniżej, na jeszcze bardziej problematyczne konsekwencje narażone jest twierdzenie, że Parmenides monistą numerycznym nie był. Curd bowiem, broniąc tezy o właściwym odczytaniu Parmenidesa przez wspomnianych wyżej presokratyków, zmuszona jest uznać, że nie tylko Zenon i Melissos (tj. jego domniemani kontynuatorzy w szkole elejskiej) nie zrozumieli Parmenidesa, ale też że nie rozumieli go Platon i Arystoteles.

W niniejszej pracy postaram się wykazać, że interpretacja myśli Parmenidesa w duchu monizmu predykatywnego, przyjmowana przez Curd i Dariusza Kuboka, kłóci się nie tylko z treścią poematu Eleaty, lecz także z tym, jak interpretowali jego filozofię inni starożytni myśliciele, na czele $z$ Platonem. Interpretacja ta zmusza nas do wyłączenia z grupy filozofów eleackich Zenona z Elei i Melissosa z Samos i uznania za filozofów eleackich m.in. Empedoklesa, Anaksagorasa czy też samego Platona. Ostatecznie postaram się wykazać, że interpretacja w duchu monizmu numerycznego lepiej oddaje intencje poematu Eleaty i daje się pogodzić z późniejszą recepcją jego myśli, a ponadto samego Parmenidesa możemy uważać za prekursora idealizmu ${ }^{3}$.

Ponieważ głównym przedmiotem pracy jest krytyka stanowiska Curd i Kuboka, powstrzymuję się przed dokładniejszym wyłożeniem własnej interpretacji filozofii Parmenidesa, jako że (jak sądzę) zaburzyłoby to strukturę wywodu $\mathrm{w}$ tak krótkim tekście, jakim z konieczności jest artykuł. $\mathrm{Z}$ tego też powodu nie omawiam szerszej problematyki, jaka wiąże się z jego myślą. Z racji faktu, że badania nad Parmenidesem toczą się od tak dawna i powstało tak wiele prac mu poświęconych, sądzę, iż adekwatne ujęcie filozofii Eleaty wymagałoby takiego rozwinięcia niniejszej pracy, iż musiałaby ona przyjąć formę monografii.

\section{Monizm predykatywny}

Curd uznaje Parmenidesa za „monistę predykatywnego”. Monizm predykatywny, w przeciwieństwie do monizmu numerycznego, jest stanowiskiem, które dopuszcza istnienie wielu bytów, o ile spełniają one warunek jedności, tj. posiadają

later Presocratic thinkers or claim that they felt free to ignore his argument while accepting certain of his assumptions about what-is".

3 Na potrzeby niniejszej pracy przez idealizm rozumiem stanowisko przeciwne materializmowi. Jednakże zdaje sobie sprawę, iż utożsamienie idealizmu z immaterializmem nie jest czymś niekontrowersyjnym. Por. J. Dunham i in., Idealism, Routledge, London, New York 2011, s. 10-13. 
pewną istotę, która zapewnia im jedność ${ }^{4}$. Zdaniem Curd interpretacja ta tłumaczy wzajemne powiązania między Parmenidesem a późniejszymi presokratykami i niejako stawia ich w nowym świetle, czyli jako kontynuatorów myśliciela z Elei.

Stanowisko monizmu predykatywnego znalazło swych apologetów na gruncie polskim. W tym właśnie duchu Dariusz Kubok interpretuje Parmenidesa, choć wydaje się, że jego stanowisko raczej zasługuje na miano monizmu werytatywno-predykatywnego. Kubok, podobnie jak Curd, uznaje, że w poemacie Parmenidesa nie odnajdujemy dowodów na numeryczny monizm Eleaty i dopuszcza on istnienie wielu bytów. Jednocześnie Kubok uznaje (jak sam podkreśla, pod wpływem badań Kahna ${ }^{5}$ ), iż owymi istotami, o jakich pisze Curd, jest prawda czy też prawdy:

Poemat Parmenidesa jest pierwszym dziełem filozoficznym, które tematyzuje problem prawdy i jej związki z bytem. Prawda staje się dla Eleaty centralnym zagadnieniem, wokół którego ogniskują się inne problemy $y^{6}$.

Według powyższej egzegezy poematu Parmenides nie opisuje jednego jedynego bytu „do pięknie zaokrąglonego ciała kuli podobnego", lecz prawdę rozumianą jako istotę rzeczy ${ }^{7}$. Jest to, jak już wspomniano, interpretacja niewątpliwie oryginalna i budząca skojarzenia z systemem Platońskim, skoro - zdaniem Curd i Kuboka - wizja Parmenidesa dopuszcza wielość istniejących przedmiotów.

Dzięki temu system Eleaty daje się pogodzić nie tylko z filozofią Platona, lecz także, jak już wspomniano, z rozważaniami filozofów przyrody jak Demokryt, Empedokles czy Anaksagoras. Dzieje się tak z uwagi na fakt, że każdy z tych filo-

Tamże, passim.

5 Co ciekawe, Kubok opiera swą interpretację na filologicznych dokonaniach Kahna, zdaniem którego z kolei w czasach Parmenidesa nie dominowało egzystencjalne rozumienie estin, lecz werytatywno-predykatywne. Niemniej jednak Kahn, w przeciwieństwie do Kuboka, uznaje Parmenidesa za monistę numerycznego. Zob. Ch.H. Kahn, Being in Parmenides and Plato, w: tegoż, Essays on Being, Oxford University Press, New York 2009, passim. Podobną interpretację co Kubok przedstawia Blandzi i podkreśla, że problematyką podejmowaną przez Parmenidesa jest problematyka Prawdy. Zob. S. Blandzi, Między aletejologią Parmenidesa a ontologia Filona, Wydawnictwo IFIS PAN, Warszawa 2013, s. 44: „[...] Jedynie PRAWDA jako taka, spełnia całkowicie warunek tego, co JEST, bycia Bytem".

6 D. Kubok, Prawda i mniemania. Studium filozofii Parmenidesa $z$ Elei, Wydawnictwo Uniwersytetu Śląskiego, Katowice 2004, s. 107.

7 Tamże, s. 135. 
zofów przyjmował, że choć przedmioty zjawiają się na wiele różnych sposobów, to ich istota jest jedna ${ }^{8}$. Jak twierdzi Kubok:

Prawda (istota) czegoś jest jedna, wiele natomiast sposobów zjawiania się czegoś [...]. Parmenides nie twierdzi, że jest tylko jeden byt jako całość wszystkich rzeczy, lecz stwierdza, że prawda (istota, to, czym coś w istocie jest) jest jedna9.

Wydaje się, że interpretacja ta daje się obronić na gruncie „drogi prawdy”. Już na samym początku swego monologu bogini zaznacza, że młodzieniec musi poznać „prawdy pięknie zaokrąglonej niewzruszone serce” (B1, 1.29) ${ }^{10}$, i kończy go słowami „w tym miejscu kończę wiarygodny logos i myśl o prawdzie” (B8, 8.50-51) ${ }^{11}$. Jednak oczywiste jest, że owe fragmenty nie są wystarczającym dowodem potwierdzającym słuszność tezy Kuboka, choć rzeczywiście dają pewne podstawy do interpretacji innych niż ściśle monistycznej.

Nietrudno zauważyć, że taka interpretacja dzieła O naturze wydaje się rozwiązywać wiele problemów, jakie napotykali interpretatorzy myśli Parmenidesa (na czele $\mathrm{z}$ „kłopotliwym” monizmem numerycznym), i zaprzecza Platońskiemu ojcobójstwu z Sofisty ${ }^{12}$. Kubok stara się bowiem wykazać, że de facto ostrze krytyki w Sofiście nie jest skierowane przeciwko Parmenidesowi $^{13}$, lecz przeciwko Ksenofanesowi i innym (np. Melissosowi), którzy - w przeciwieństwie do Eleaty - mieli utrzymywać stanowisko monizmu numerycznego. Warto tu jednak wspomnieć, iż niektórzy badacze nie w Ksenofanesie czy Parmenidesie, ale w Zenonie widzieli pierwszego myśliciela, który stanął na stanowisku monizmu numerycznego. Poglądy co do pierwszeństwa Zenona w sformułowaniu tezy monizmu numerycznego stawia $\mathrm{Curd}^{14}, \mathrm{Palmer}^{15}$

Tamże, s. 189.

Tamże.

10 Tłum. K. Mrówka.

11 Tłum. K. Mrówka.

12 Co prowadzi nas do konkluzji, że zgodnie z tą interpretacją Platon nie zrozumiał myśli Parmenidesa do tego stopnia, że nie zauważa, iż de facto jego pogląd jest niemalże tożsamy z poglądami Eleaty. Zważywszy na fakt, że zdaniem Curd Parmenidejskie byty są niecielesne (incorporeal), nie widzę przeszkód, by określić je mianem istot.

13 Jednak D. Kubok wydaje się nie być zdecydowany co do tego, jak Platon rozumiał Parmenidesa. Zob. Argument $z$ recepcji w niniejszej pracy.

14 P. Curd, dz. cyt., s. 178-179.

15 J. Palmer, Parmenides and Presocratic Philosophy, Oxford University Press, New York 2009, s. 214-215. 
i Mourelatos ${ }^{16}$. Barnes z kolei widzi pierwszego monistę w Melissosie ${ }^{17}$. Jak już zostało wspomniane, w wyniku omawianej interpretacji postparmenidejscy pluraliści jawią się jako kontynuatorzy Parmenidesa czy wręcz jako eleaci - tj. myśliciele w całości respektujący Parmenidejską drogę Prawdy. Nie jest to jednak, jak się wydaje, zgodne ze znanymi nam źródłami historycznymi, które do szkoły eleackiej obok Parmenidesa zaliczają tylko Zenona ${ }^{18}$ i Melissosa ${ }^{19}$. Trzeba również zauważyć, że myśl Zenona i Melissosa ma charakter głównie polemiczny, tak jakby była reakcją na toczącą się debatę.

\section{Argument z recepcji}

Zarówno Curd, jak i Kubok, jednocześnie „ratując honor” presokratyków, przez próbę wykazania zbieżności ich poglądów z myślą Parmenidesa są skazani na to, by uznać, że późniejsi filozofowie - na czele z Platonem i Arystotelesem - błędnie odczytali myśl Parmenidesa. Jak zobaczymy, gdy rozszerzymy perspektywę na poglądy głoszone przez Platona ${ }^{20}$, stanowisko Curd i Kuboka okaże się nie do utrzymania.

Już sam fakt, że w kontekście proponowanej interpretacji Kubok i Curd zaliczają do jednej i tej samej szkoły elejskiej Parmenidesa, Ksenofanesa, Zenona

16 Zob. A.P.D. Mourelatos, The Route of Parmenides, Parmenides Publishing, Las Vegas 2008, s. 132.

17 Zob. J. Barnes, The Presocratic Philosophers, Routledge, London 2005, s. 162.

18 Ponadto Zenon już w starożytności przedstawiany był jako najwierniejszy uczeń Parmenidesa i skrajny monista (m.in. przez Platona), i to właśnie przez pryzmat tego, co mówi nam Zenon, powinniśmy odczytywać myśl Eleaty. Myśli Zenona i jej związkom z filozofią Parmenidesa poświęcam oddzielny artykuł. Zob. A. Uchan, Zenon z Elei i eleacki immaterializm, „Przegląd Filozoficzno-Literacki", (przyjęty do druku).

19 Warto tu jednak zaznaczyć, że do filozofii eleatów w swych rozważaniach nawiązywali przedstawiciele szkoły megarejskiej Euklidesa, łącząc ją z myślą Sokratesa. Zob. G. Reale, Historia filozofii starożytnej, t. I, tłum. E.I. Zieliński, KUL, Lublin 2008, s. 430-433.

20 Mourelatos uważa, że Parmenides Platona nie jest tożsamy z Parmenidesem historycznym (zob. Mourelatos, dz. cyt., s. 130.). Niemniej jednak, zważywszy na fakt, że Platona dzieliło od Parmenidesa zaledwie kilkadziesiąt lat, a jak sam wspomina w swym Parmenidesie, Eleata miał przybyć do Aten jeszcze za życia Sokratesa - co może sugerować, że Platon mógł mieć kontakt z jeszcze żywą eleacką myślą - to możemy przypuszczać, iż Platoński Parmenides jest bliski Parmenidesowi historycznemu. Mimo to kwestia ta nie jest ani jasna, ani łatwo rozstrzygalna. O Platońskiej recepcji Parmenidesa szerzej pisze Palmer. Zob. J.A. Palmer, Plato's Reception of Parmenides, Clarendon Press, Oxford 1999. 
i Melissosa, budzi wielkie wątpliwości. Jak bowiem rozumieć fakt, że (zakładając, iż filozof z Kolofonu należał do grona eleatów, co jest wielce wątpliwe ${ }^{21}$ ) monizm Ksenofanesa i Melissosa miałby tak skrajnie się różnić od poglądów Eleaty? Dlaczego w ogóle mielibyśmy w takim wypadku zaliczać Parmenidesa do szkoły elejskiej, o której Platon mówi: „A nasza grupa, eleatów, od czasów Ksenofanesa i jeszcze dawniej mówi, że jednym jest to, tak zwane wszystko, co istnieje [...]"22. Czyżby Parmenides porzucił nauki swego (domniemanego) mistrza o Jednym $(\tilde{\varepsilon} v)$ i w swym poemacie przedstawił pluralistyczną wizję świata, a jednocześnie nauczał tak nieudolnie, że późniejsi filozofowie - na czele z Zenonem, Melissosem, Platonem i Arystotelesem - nie zrozumieli tego, co chciał przekazać w swym poemacie? Czy może zrozumieli go, lecz celowo zniekształcili jego myśl, by móc przypisać mu monizm? Obie hipotezy wydają się mało prawdopodobne.

Jak już wspomniano, przyjmując interpretacje Curd i Kuboka, tacy filozofowie jak Anaksagoras, Empedokles czy nawet atomiści byliby eleatami, jako że w ich myśli Curd dostrzega Parmenidejski monizm predykatywny (którego nie można doszukać się u Zenona i Melissosa). Jednak wydaje się jasne, że tzw. paradoksy Zenona $\mathrm{z}$ Elei skierowane były właśnie przeciw tezie o istnieniu wielu bytów ${ }^{23}$. Podobnie rzecz się ma w przypadku myśli Melissosa ${ }^{24}$. Wydaje się więc, że kontrargumenty Zenona i Melissosa skierowane przeciw pluralizmowi godzą w (domniemany) Parmenidejski monizm predykatywny (jako że Curd uznaje Anaksagorasa i Empedoklesa za myślicieli respektujących droge prawdy). Co więc miałoby z Zenona i Melissosa czynić eleatów? Co miałoby ich wiązać z Parmenidesem? Wydaje się, że poglądy wskazujące, jakoby Parmenides nie był monistą numerycznym, wynikają $\mathrm{z}$ tego, że wielu interpretatorów myśli Eleaty nie dostrzega faktu, że należy myśl Parmenidesa badać w połączeniu z myślą Zenona i Melissosa. Dzięki tak skonstruowanej szerszej perspektywie klaruje się obraz tego, czym była szkoła elejska, i wyklucza możliwość przypisania Parmenidesowi

21 Reale uważa, iż poza świadectwem Platona nie znajdujemy w źródłach dostatecznych dowodów, by uznać Ksenofanesa za eleatę. Zob. G. Reale, dz. cyt., s. 129-131. Również Mrówka zwraca uwagę na problem wiązania Ksenofanesa z eleatami. Zob. K. Mrówka, Parmenides. Ścieżka Prawdy, PWN, Warszawa 2012, s. 17.

22 Platon, Sofista, 242d, tłum. W. Witwicki, Antyk, Kęty 2002.

23 Curd uznaje, że argumenty Zenona były skierowane przeciw Anaksagorasowi i Empedoklesowi. Zob. P. Curd, dz. cyt., s. 17. G.S. Kirk, J.R. Raven i M. Schofield wprost stwierdzają, że tzw. paradoksy Zenona uderzają również w myśl Parmenidesa. Zob. G.S. Kirk i in., Filozofia przedsokratejska, tłum. J. Lang, PWN, Warszawa 1999, s. 268. 
monizmu predykatywnego. Należy również wziąć pod uwagę to, że wymienieni filozofowie nie dość, że posługiwali się starogreckim lepiej od jakiegokolwiek dzisiejszego egzegety myśli starożytnych Greków, to jeszcze prawdopodobnie mieli kontakt nie tylko z całym poematem $O$ naturze (jak wiadomo, do naszych czasów nie zachował się on w całości), lecz także z przekazem ustnym ${ }^{25}$.

Jak podkreśla Kahn, z tego właśnie powodu myśl Platona może posłużyć nam jako klucz do interpretacji filozofii Eleaty:

Miał on [Platon] możliwość zapoznania się z kompletnym tekstem, bezpośrednią znajomość języka, a być może nawet kontakt z ustną tradycją eleatyzmu. Był więc w lepszej sytuacji niż my, gdy próbujemy zrozumieć, co Parmenides miał na myśli. Dzięki temu, że Platon przekazał nam pełne i jasne stanowisko swej własnej koncepcji Bytu, ta właśnie koncepcja, użyta z należytą troską, może nam pomóc zinterpretować bardziej lapidarne i zagadkowe wypowiedzi Parmenidesa ${ }^{26}$.

Analiza tego, co Platon przekazuje w swych dialogach na temat swego „ojca” (jak określa on Parmenidesa w swym Sofiście), może nam pomóc właściwie zrozumieć myśl Eleaty. Jak zauważył Gallop, nawiązując do słynnej sentencji Whiteheada, myśl Platona jest tak mocno zależna od eleatyzmu, że możemy ją uznać za zbiór przypisów do Parmenidejskiej metafizyki ${ }^{27}$.

Problem recepcji myśli Parmenidesa jest węzłowym punktem, w którym Kubok wydaje się przedstawiać dwie różne interpretacje tego, jak Parmenidesa odczytywał Platon. Z jednej strony stwierdza:

Tradycja pośrednia, a w szczególności pisma Platona i Arystotelesa, przedstawiają Parmenidesa jako skrajnego monistę, dla którego właściwym przedmiotem dociekań [...] jest „Jedno”28.

25 Jeżeli opisane w Platońskim Parmenidesie spotkanie Sokratesa z Parmenidesem i Zenonem rzeczywiście się odbyło, to Platon mógł znać poglądy eleatów od Sokratesa.

26 „He had the advantage of a complete text, an immediate knowledge of the language, and perhaps even an Eleatic tradition of oral commentary. So he was in a better position than we are to understand what Parmenides had in mind. Since Plato has given us a much fuller and more explicit statement of his own conception of Being, this conception, if used with care, may help us interpret the more lapidary and puzzling utterances of Parmenides himself" Ch.H. Kahn, dz. cyt., s. 167.

27 D. Gallop, Parmenides of Elea, University of Toronto Press, Toronto, Buffalo, London 1991, s. 3.

D. Kubok, dz. cyt., s. 182. 
Z kolei w rozdziale poświęconym „domniemanemu ojcobójstwu” stwierdza, że Platon zdawał sobie sprawę z faktu, iż Eleata nie był monistą:

[...] Parmenides w żadnym fragmencie nie twierdzi, że wszystko jest Jednem; co więcej, тò $\pi \tilde{a} v$ nie występuje we fragmentach dotyczących drogi prawdy, tylko w odniesieniu do mniemań śmiertelnych (B 9). Platon ma świadomość tego faktu $[\ldots]^{29}$.

Warto też zwrócić uwagę na fakt, że w Platońskim Parmenidesie podejmującym temat Jedna, główną postacią dialogu jest właśnie Eleata. Kubok jednak, na przykładzie Teajteta, w którym również jest podejmowany problem Jedna, stara się udowodnić, iż Platon wcale nie przypisywał Parmenidesowi monizmu absolutnego:

Platon ma świadomość tego faktu [że Parmenides nie był monistą], gdyż nie przypisuje owego stanowiska Parmenidesowi, lecz mówi, [...] że stanowisko takie głoszą „Melissosowie i Parmenidesowie” [...]. Można więc przypuszczać, że pogląd taki charakterystyczny jest dla myślicieli, którzy nawiązują do eleatów i - jak się okazuje - zniekształcają oryginalną myśl Parmenidesa ${ }^{30}$.

Na czym jednak miałoby polegać to nawiązanie, skoro Parmenides miał zdaniem Kuboka nie być monistą? Poza tym już sam fakt, że Platon zestawia „Melissosów" (Kubok sam wielokrotnie przyznaje, że myśliciel z Samos był monistą numerycznym) z „Parmenidesami” i stwierdza, iż głoszą oni (łącznie) stanowisko monistyczne, wyraźnie pokazuje, że Platon także przypisywał to stanowisko Eleacie.

Również Curd nie jest jednoznaczna w swym obrazie Platona. Ma bowiem rację, gdy zauważa, że monizm predykatywny jest tezą, którą można pogodzić z Platońską teorią idei, czy wręcz że Platoński idealizm jest rozwinięciem tezy monizmu predykatywnego ${ }^{31}$. W interpretacji Curd Platon byłby najwierniejszym kontynuatorem Parmenidesa - o wiele wierniejszym niż skrajni moniści tacy jak Zenon czy Melissos. Dlaczego więc Curd zalicza tych dwóch myśliciel do grona eleatów, a Platona nie?

\footnotetext{
Tamże, s. 333-334.

Tamże, s. 334.

P. Curd, dz. cyt., s. 233.
} 
Na poparcie swych tez o relacji między Platonem a Parmenidesem Curd odwołuje się również do Platońskiej metafizyki i obrazu Piękna z Platońskiej Uczty. Słusznie zauważa, że Platon przy opisie Piękna-samego-w-sobie posługuje się tymi samymi stwierdzeniami, którymi posługuje się Parmenides przy opisie tego-co-jest ${ }^{32}$. Nie zauważa ona jednak, że Platońskie Piękno-samo-w-sobie jest przede wszystkim j e d n o ${ }^{33} \mathrm{i}$ istnieje samo przez się - wszystko poniżej (świat zmysłowy, ale też i idee) właśnie od niego czerpie swą bytowość. Platon nie opisuje Parmenidejskimi słowami wszystkich idei, ale wyłącznie jedną. Zatem jeżeli tylko to, co jest na szczycie Platońskiego świata, spełnia wymagania drogi prawdy (a Platon słowami Parmenidesa opisuje właśnie tylko jedno Piękno-samo-w-sobie, i nic innego), to nie można uważać, że Platon nie uważał Parmenidesa za monistę. Platon ma świadomość faktu, iż Parmenidejski monizm zdaje się godzić w możliwość istnienia tzw. świata zmysłowego. W celu ratowania świata zjawisk i wielości uznał on, że trzeba (wbrew swemu „ojcu”), obok Bytu, przyjąć również istnienie nie-bytu, który jest konieczny (zdaniem Platona), by wytłumaczyć wielość świata zjawisk. To właśnie nie-byt jest tym, co zdaniem Platona może tłumaczyć istnienie wielości. Na tym właśnie polega Platońskie ojcobójstwo. Prócz jednego absolutnego Bytu istnieją byty, które mają w sobie domieszkę nie-bytu ${ }^{34}$, a istnieją tylko dlatego, że swe istnienie zawdzięczają jednemu Bytowi będącemu na szczycie Platońskiego świata ${ }^{35}$ (co znajduje swój wyraz w Platońskiej metaforze jaskini przedstawionej w Państwie $\left.{ }^{36}\right)$.

32 Tamże, s. 228.

33 Jak zauważa Karl Albert, Arystoteles, komentując metafizyczny system Platona, wyraźnie zaznacza twierdzenia platoników, że rzeczy istnieją dlatego, iż uczestniczą w ideach. Jednak same idee czerpią swe istnienie od Jedni i to właśnie Jednia (którą można utożsamić z Bytem, Dobrem i Pięknem) istnieje w najpełniejszym sensie. Zob. K. Albert, O platońskim pojęciu filozofii, tłum. Jerzy Drewnowski, Wydawnictwo IFiS PAN, Warszawa 1991, s. 41-42.

34 Platon, Sofista, s. 258a-259b.

35 Taki obraz rzeczywistości znajdziemy również u neoplatoników, w tym również u Plotyna, który widział w Parmenidesie monistę i pierwszego filozofa opisującego Byt niezmysłowy. Zob. Plotyn, Enneady, t. II, tłum. A. Krokiewicz, PWN, Warszawa 1959, s. 222. Jak zauważa Coxon, Proklos w swej interpretacji myśli Eleaty próbował go wręcz uczynić neoplatonikiem. Zob. A.H. Coxon, dz. cyt., 2009, s. 37.

36 Słońce, które symbolizuje ów najwyższy Byt-Dobro, opisywane jest przez Platona jako to, co jest zasadną wszelkiego istnienia: ,[...] Od niego pochodzą pory roku i lata [...], ono rządzi wszystkim w świecie widzialnym, [...] jest w pewnym sposobie przyczyną także i tego wszystkiego, co oni tam poprzednio widzieli”. Zob. Platon, Państwo, tłum. W. Witwicki, Wydawnictwo Antyk, $516 \mathrm{c}$. 
Również Arystoteles wielokrotnie potwierdza w swych pismach fakt głoszenia przez Parmenidesa stanowiska konsekwentnie monistycznego, co zauważa sam Kubok ${ }^{37}$. Jak zauważa Kazimierz Leśniak, Arystoteles wyraźnie wyróżniał eleatów spomiędzy innych presokratyków, uznając, że to właśnie oni jako pierwsi podjęli badania metafizyczne, a nie fizyczne (tj. kosmologiczne). Dlatego też, gdy opisuje myśl innych presokratyków w Fizyce, wyraźnie odróżnia od nich eleatów ${ }^{38}$. Arystoteles również jasno w swym $O$ powstawaniu i ginięciu przypisuje eleatom monizm numeryczny i zaznacza, że przedmiotem rozważań eleatów była rzeczywistość rozumiana jako całość utożsamiana przez nich z Bytem ${ }^{39}$.

\section{Problem Jedna}

Interpretacja predykatywna zakłada, że może istnieć obok siebie wiele bytów (co czyni z tego poglądu stanowisko pluralistyczne $)^{40}$. Godzi to w obraz Parmenidesa jako konsekwentnego monisty, który znamy od wieków, a który, jak wskazano wyżej, przekazali nam chociażby Platon czy Arystoteles. Jednak aby dobrze zrozumieć myśl Eleaty, powinniśmy również rozstrzygnąć, na ile wyraźnie on sam poświadcza o swym monizmie w swoim poemacie.

Chcąc bronić tezy o pluralizmie Eleaty, tj. o tym, że Parmenidejska droga prawdy dopuszcza wielość, trzeba zmierzyć się z pojawiającym się we fragmencie B 8 określeniem bytu: $\tilde{\varepsilon} v$. Kubok podkreśla fakt, że samo pojęcie „Jeden” pojawia się w całym poemacie tylko raz, jako jeden ze znaków drogi prawdy, a pojęcie „Jedno" ( $\tau \dot{c} \varepsilon \mathscr{v})$ nie pojawia się ani razu ${ }^{41}$. Zdaniem badacza wynika stąd wniosek,

37 D. Kubok, dz. cyt., s. 376-386.

38 Jak stwierdza Leśniak, Stagiryta, używając termin $\varphi v \sigma \iota k o$, nie określa tym mianem eleatów. Jak zauważa: „Arystoteles ma na myśli [gdy mówi o $\varphi v \sigma ı \kappa o l$ głównie jońskich filozofów przyrody oraz Empedoklesa, Anaksagorasa i atomistów w odróżnieniu od eleatów i pitagorejczyków, których poglądy miały charakter wybitnie metafizyczny". Zob. Arystoteles, Fizyka, tłum. K. Leśniak, PWN, Warszawa 1968, s. 307.

Arystoteles, O powstawaniu i ginięciu, PWN, Warszawa 1981, 325a.

40 Również Barnes nie uznaje Parmenidesa za monistę: „,Was Parmenides a monist? The surviving fragments do not make him one. Since we are fairly confident of possessing the whole of the Way of Truth, I incline to believe that Parmenides' poem was not monistic. And since we hear nothing of any Parmenidean doctrine not included in the Way of Truth, I suspect that Parmenides was not a monist. At all events, as far as our evidence goes, real monism was an invention of Melissus". Zob. J. Barnes, dz. cyt., s. 163-164.

D. Kubok, dz. cyt., s. 183. 
iż kwestia „Jedna” nie stanowi centralnego problemu w rozważaniach mędrca z Elei.

Prawdą oczywiście jest, że atrybut jedności w O naturze pojawia się explicite tylko raz, jednakże nie można przeoczyć tego, iż Parmenides od początku swego poematu mówi o bycie w formie pojedynczej, co zauważa również Mrówka ${ }^{42}$. Reale $\mathrm{z}$ kolei stwierdza, że jedność eleackiego bytu wypływa niejako z jego innych określeń, a sam Eleata dodaje ją „przelotem"43. Wydaje się zatem, że interpretacja pluralistyczna (w przeciwieństwie do interpretacji monistycznej) nie dość, że stoi w sprzeczności z tym, co o Parmenidesie mówią jego współcześni, to nie znajduje ona żadnego oparcia w dziele Eleaty. Rację więc ma Mrówka, pisząc:

Należy jednak przyjąć, że jedno Parmenidesa, bez względu na to, czy uznamy je za pojęcie równorzędne pojęciu bytu, czy też dostrzeżemy w nim jedno z jego wielu określeń (znaków), mówi nam w obu wypadkach to samo: jest tylko jeden jedyny byt i nie ma poza nim żadnego innego, jest oũ „całe Jedyne"44.

Warto tu jeszcze wspomnieć o stanowisku Pacewicza, który, recenzując pracę Kuboka, stwierdza, że monistyczna interpretacja myśli Parmenidesa wydaje się, mimo twierdzeń autora, zasadna. Zauważa on, że zarówno Platon, jak i Arysto-

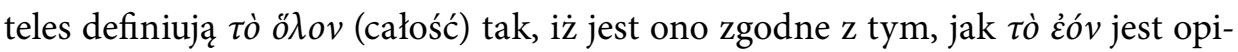
sane na drodze Prawdy ${ }^{45}$. Ponadto Pacewicz zwraca uwagę na fakt, iż słowo $\pi \tilde{\alpha} v$, w różnych formach, pojawia się wielokrotnie w samym poemacie:

Przymiotnik ten pojawia się wielokrotnie w różnych formach $\mathrm{w}$ poemacie Parmenidesa, ale chciałbym przede wszystkim zwrócić uwagę na jego formę rodzaju nijakiego w liczbie pojedynczej, która pięciokrotnie pojawia się we frag. 8, mówiącym o tym, co jest/prawdzie, i tylko raz we frag. 9, dotyczącym świata zmysłowego ${ }^{46}$.

\footnotetext{
K. Mrówka, dz. cyt., s. 228.

G. Reale, dz. cyt., s. 145.

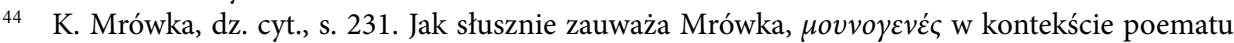
nie można tłumaczyć jako „raz zrodzony”, stałoby to w sprzeczności z innym określeniem bytu, jakim jest $\dot{\alpha} y \varepsilon ́ v \eta \tau o v$, tj. niezrodzony. Zatem trzeba przyjąć tłumaczenie ,jedyny”, co przemawia za interpretacją monizmu numerycznego. Zob. tamże, s. 221.

45 Zob. D. Kubok, Prawda i mniemania. Studium filozofii Parmenidesa $z$ Elei, Katowice 2004, rec. A. Pacewicz, „Roczniki Filozoficzne” 2006, nr 1(54), s. 274-275.

46 Tamże, s. 275.
} 
I dalej stwierdza, iż we fragmencie B 8, w wersach 3-5 podmiotem jest દ̇óv, lecz wraz z pojawieniem się spójnika $\dot{\varepsilon} \pi \varepsilon i$ podmiotem staje się właśnie $\pi \tilde{\alpha} v^{47}$. Co ciekawe, Pacewicz zauważa, iż $\pi \tilde{\alpha} v$ pojawia się również w opisie drogi mniemań, co prowadzi go do interpretacji poematu Parmenidesa, która wydaje się, moim zdaniem, godzić z filozofią Heraklita:

[...] w wersie 3 frag. B 9 Parmenides twierdzi, iż „wszystko ( $\pi \tilde{a} v)$ jest pełne światła i nocy" oraz układa on formy w postaci kręgów, co powiązać można z obrazem tego, co jest/ prawdy jako kuli, [...] okazuje się, iż desygnatem $\pi \tilde{a} v$

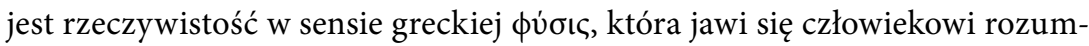

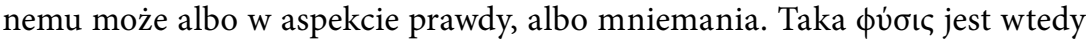
jedna, niepodzielna, ciągła ${ }^{48}$.

Warto $\mathrm{w}$ tym miejscu wspomnieć, iż mędrzec z Efezu, przedstawiając świat jako arenę walki przeciwieństw, stwierdza wyraźnie, że owe przeciwieństwa tworzą pewną harmonię, jedność, i twierdzi:

Nie mnie [...] - lecz głosu rozumu słuchając, mądrze jest przyznać, że wszystkie rzeczy stanowią jedność ${ }^{49}$.

Pamiętać trzeba, że Heraklit głosił pogląd o przenikającym wszystko Logo$\mathrm{sie}^{50}$. Samo pojęcie logosu jest wieloznaczne - można je tłumaczyć jako dyskurs, słowo, mowę, ale też rozum. W proponowanej tu egzegezie Parmenides, wraz z Heraklitem, byliby filozofami jednoczącymi wielość świata zmysłów w jedność Logosu. Jak niżej zobaczymy, wydaje się, że Eleata utożsamia świat z rozumem-myślą. Czy jednak możemy zatem o nim mówić jako o ojcu idealizmu?

\section{Bycie i myślenie}

Aby odpowiedzieć na tak postawione pytanie, powinniśmy przeanalizować ten fragment $O$ naturze, który zdaje się wskazywać na nierozerwalną relację między myśleniem a byciem. Jest to szczególnie ważny fragment B3, o którym Henn mówi, iż ten, kto nie zrozumie przesłania z niego płynącego, nie zrozumie prze-

47 Tamże.

48 Tamże.

49 Cyt. za G. Reale, dz. cyt., s. 473.

50 K. Mrówka, Heraklit, Scholar, Warszawa 2004, s. 22-34. 
słania płynącego z całego poematu ${ }^{51}$. Jak zauważa Kubok ${ }^{52}$, w owej relacji między byciem a myśleniem wielu filozofów i egzegetów poematu Parmenidesa dopatrywało się idealizmu i aprioryzmu Eleaty ${ }^{53}$ (jak zostanie wskazane - słusznie). Owen $\mathrm{z}$ kolei podkreśla fakt, że to właśnie $\mathrm{w}$ tym miejscu Parmenides jawi się jako filozof radykalnie różny od dotychczasowych myślicieli, i uznaje wręcz, że Eleata antycypuje myśl Kartezjusza i jego słynne cogito ergo sum ${ }^{54}$, z czym zgadza się również Henn ${ }^{55}$.

Co zatem Parmenides mówi nam o związku między myśleniem a byciem? W B3 stwierdza:

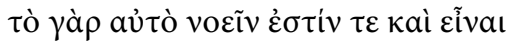

Mrówka oddaje to jako: „To samo bowiem myśleć jest, i być”, i jak zauważa, fragment ten jest interpretowany na trzy sposoby:

1. Podkreśla się rolę myślenia;

2. Większą wagę przypisuje się byciu;

3. Uznaje się równoważność myślenia i bytu.

Pierwsza $\mathrm{z}$ interpretacji prowadzi do uznania, że to byt jest zależny od myślenia i to ono warunkuje jego istnienie. Jeżeli byłaby to prawda, uznać by można (jak czyni to Jonathan Barnes), że Parmenides antycypuje Berkeleyowskie esse est percipi $i^{56}$. Wydaje się jednak, że takie rozumienie związku między bytem a myśleniem nie dość, że spycha byt na pozycje czegoś niesamoistnego, zależnego od myślenia, to (co ważniejsze) nie daje się pogodzić z eleackim monizmem - samemu myśleniu, by mogło istnieć, musi przynależeć bycie. Wydaje się więc, że tezę o pierwszeństwie myślenia należy porzucić jako nie do utrzymania w perspektywie Parmenidejskiego monizmu.

Interpretacja druga, utrzymana w duchu realizmu, przyznaje pierwszeństwo bytowi, uznając, że to właśnie on warunkuje myślenie (stanowisko to zdaje się

\footnotetext{
Zob. M.J. Henn, Parmenides of Elea, Praeger, London 2003, s. 54.

D. Kubok, dz. cyt., s. 137.

53 Jak zauważa Dunham, fragment B3 był źródłem co najmniej trzech różnych idealistycznych interpretacji myśli Parmenidesa. Widziano w nim wyraz: panpsychizmu, obiektywnego idealizmu i subiektywnego idealizmu. Zob. J. Dunham, dz. cyt., s. 16.

54 G.E.L. Owen, dz. cyt., s. 16.

55 Trzeba zaznaczyć jednak, że podobieństwa między tym myślicielami na tym się kończą z racji faktu, że Kartezjusz był dualistą, z kolei Parmenides monistą. Zob. M.J. Henn, dz. cyt., s. 55.

56 J. Barnes, The Presocratic Philosophers, Routledge, London 1982, s. 170-171.
} 
reprezentować Kubok ${ }^{57}$, a także Blandzi ${ }^{58}$ ). Badacze uznający ową interpretację przyjmują, że to dzięki temu, iż istnieje byt, możliwe jest myślenie, ponieważ aby myślenie miało treść, potrzebne jest coś, co je wypełni. Lecz podobnie jak w przypadku wcześniejszej interpretacji, również i ta wydaje się nie do pogodzenia ze ścisłym monizmem Eleaty, co będzie bardziej widoczne po omówieniu trzeciego możliwego odczytania.

Jak stwierdza Mrówka, ostatnia interpretacja jawi się ze względu na formę gramatyczną zdania z B3 jako najbardziej oczywista ${ }^{59}$. Również numeryczny monizm Parmenidesa skłania do takiego rozumienia relacji byt-myśl, co zauważa Drozdek:

Tylko Byt istnieje, a zatem myślenie jest tym samym, co istnienie, tj. myślenie jest tym samym, co Byt $[\ldots]^{60}$.

W podobny sposób argumentuje Kahn:

Dlaczego Parmenides powinien utożsamić myślenie z jego przedmiotem, prawdziwy sąd z tym, o czym sąd orzeka? Odpowiedź jest, jak sądzę, prosta: myślenie jest albo nie jest. Albo wiedza i prawdziwe wypowiedzi są Bytem, albo są niczym, nie istnieją. Ta alternatywa jest rozłączna: nie ma tu nicze-

$57 \quad$ D. Kubok, dz. cyt., s. 146.

58 S. Blandzi, dz. cyt., s. 50-51.

59 Podobną interpretację przyjmuje Phillips, i co ciekawe, na jej podstawie przypisuje eleacie stanowisko idealistyczne: ,[...] Parmenides can be called an idealist, who believes that what can be thought must be real”. Zob. E.D. Phillips, Parmenides on Thought and Being, „Philosophical Review" 1955, nr 4, s. 556. Z kolei Dunham uznaje, że tłumaczenie B3, utożsamiające ze sobą byt i myśl, jest „najprostsze” (the simplest). Zob. J. Dunham, dz. cyt., s. 14. Z kolei przeciw takiemu odczytaniu myśli Parmenidesa oponował Cornford: „I cannot believe that Parmenides meant: «To think is the same thing as to be». He nowhere suggests that his One Being thinks, and no Greek of his date or for long afterwards would have seen anything but nonsense in the statement that «A exists» means the same thing as «A thinks»". Zob. F.M. Cornford, Plato and Parmenides, Kegan Paul, Trench, Trübner \& Co. Ltd., London 1939, s. 34. Jak stwierdza, idąc za

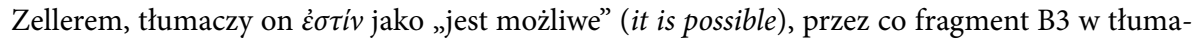
czeniu przyjmuje bardzo nieoczywistą i sztuczną formę: „To jest ta sama rzecz, o której można pomyśleć i która może być". Zob. tamże. Podobne tłumaczenie co Cornford proponuje Burnet. Zob. J. Burnet, Early Greek philosophy, Adam and Charles Black, London 1908, s. 198. Krytykę stanowiska Cornforda i Burneta przeprowadza wspomniany wyżej Phillips. Zob. S. Phillips, dz. cyt., passim.

A. Drozdek, Życie jest snem Bytu, „Analiza i Egzystencja” 2011, nr 13, s. 7. 
go pomiędzy, żadnej gradacji. Wydaje się oczywiste, że Parmenides nie chce utożsamiać wiedzy i prawdy $z$ niebytem ${ }^{61}$.

Drozdek podkreśla również, iż bogini we wstępie dzieła zachęca młodzieńca,

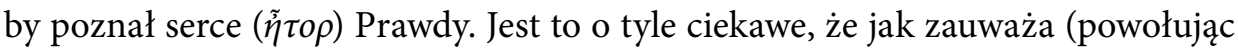
się na Coxona ${ }^{62}$ ), termin $\tilde{\eta} \tau o \rho$ występuje w ówczesnej grece wyłącznie w odniesieniu do ludzi lub postaci boskich, a z kolei Melissos mówi o eleackim bycie, że nie może odczuwać ani bólu, ani obawy, co byłoby bezsensowne, jeżeli nie byłby on czymś żywym ${ }^{63}$. Sam Coxon również dopuszcza interpretację utożsamiającą Byt z Myślą ${ }^{64}$.

Jak zauważa Gadamer, etymologia słowa voeĩv prawdopodobnie związana jest z węchem zwierzęcia, które właśnie dzięki temu zmysłowi postrzega „bez każdorazowej obserwacji”, bez refleksji i zastanowienia, że coś jest tu:

W ten właśnie sposób należy rozumieć związek między „myśleniem” i bytem u Parmenidesa, jak też i to, dlaczego w [...] B8, obok innych cech bytu, szczególny nacisk jest położony na noein. To jest tak, jakby tekst chciał nam powiedzieć, że ujawnia się jako byt bytu samego, że w swym istnieniu jest dany tak oczywiście, jak dzień ${ }^{65}$.

Oczywistość zaznaczona przez Gadamera, wynikająca z bezpośredniości uchwytywania przez rozum bytu, zdaje się sugerować brak możliwości popełnie-

${ }^{61}$ Ch.H. Kahn, dz. cyt., s. 164: „Why should Parmenides identify cognition with its object, true statement with what it states? The answer is, I think, a simple one: either it is or it is not. Either knowledge and true speech are Being or they are nothing at all. The disjunction is exclusive: there is no middle ground and no gradations. Now it seems obvious that Parmenides would not want to identify knowledge and truth with nonentity".

62 A.H. Coxon, The Fragments of Parmenides, Van Gorcum, Assen 1986, s. 168.

63 A. Drozdek, dz. cyt., s. 8.

64 A.H. Coxon, The Fragments of Parmenides, Parmenides Publishing, Las Vegas 2009, s. 297: „[...] The neoplatonic belief that P. identified Being with Mind was well-founded. Their identity is

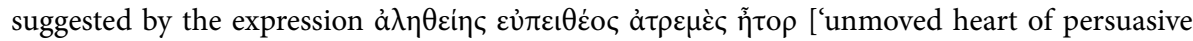

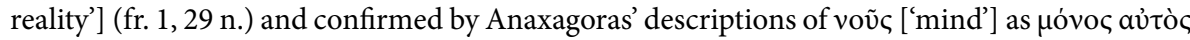

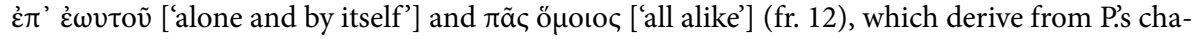

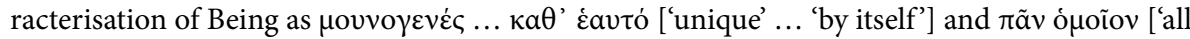
alike'] (cf. Introd. Sect. 6). Xenophanes' account of God as a mind transcending human minds in its power (fr. 23-25), since it is the immediate pattern for part of P.s account of Being (fr. 8, 29-33 n.), may also be regarded as suggesting that P. envisaged Being as Intelligence".

65 H.G. Gadamer, Poczatek filozofii, tłum. J. G. Krynicka, Wydawnictwo IFIS PAN, Warszawa 2008, s. 114. 
nia błędu w tak rozumianym myśleniu. Można by nazwać to myślenie intuicyjnym w tym sensie, że nie polega na przeprowadzaniu rozumowań, lecz właśnie na bezpośrednim uchwytywaniu ${ }^{66}$.

Zatem rzeczywistość w tej optyce byłaby czymś na kształt samomyślącej się myśli, co jak zauważa Coxon, stanowi antycypację Arystotelesowskiej koncepcji Boga $^{67}$. Czyniłoby to $z$ Eleaty pierwszego filozofa stojącego na stanowisku stricte idealistycznym. Jednak fragment B3 zdaje się również mówić (podobnie jak cały poemat), że na drodze prawdy nie możemy zanegować świata zjawisk, ponieważ odmawiając im realności, zmuszeni będziemy uznać je za nie-byt ${ }^{68}$. Wydaje się, że dwa tysiące lat później inny idealista, duchowy kontynuator szkoły eleackiej Francis Herbert Bradley ${ }^{69}$, w swym Appearance and Reality, gdzie przedstawia

66 Należy zauważyć w tym miejscu, że również w Platońskiej teorii poznania ostatni etap drogi człowieka do tego, co stanowi szczyt piramidy bytu, dokonuje się na drodze racjonalnej, ale jednocześnie nie dyskursywnej. Zob. Platon, List VII, w: tegoż, Listy, tłum. M. Maykowska, PWN, Warszawa 1987, 341c. Owa racjonalność, która przenika myśl grecką, jest tak silna, iż „racjonalizuje” ona nawet to, co wydawać się może irracjonalne. Jak zauważa Bergson, nawet mistycyzm Plotyna jest w gruncie rzeczy wciąż na wskroś racjonalny i: „Pozostaje on wierny greckiemu intelektualizmowi”. H. Bergson, Dwa źródła moralności religii, tłum. P. Kostyło, Znak, Kraków 1993, s. 216.

67 A.H. Coxon, dz. cyt., 2009, s. 340.

68 Na fakt, iż zjawiska naszego codziennego doświadczenia, czy w ogóle cały świat fenomenów, nie jest dla Parmenidesa po prostu czymś przeciwnym bytowi, jak uważali m.in. Guthrie (zob. W.K.C. Guthrie, A History of Greek Philosophy, t. II, Cambridge University Press, Cambridge 1969, s. 25) czy Tarán (Zob. L. Tarán, Parmenides, Princeton University Press, Princeton 1965, s. 78), wskazuje Henn: „Parmenides, on the contrary, does not discard empirical science as useless or untrue, as empirical science had not yet been established; in fact, the goddess extols him to learn the opinions of mortals, i.e., "to do science» in order to engage others in fruitful discourse and not to be outdone in argument (B 1.30, 8.61). Parmenides is not about undermining or discounting empirical scientific investigation. He teaches us a method for transcending the testimony of the senses through contemplation of a higher Truth beyond the veil of appearance which common sense takes for granted”. Zob. M.J. Henn, dz. cyt., s, 48. Z kolei Mrówka stwierdza: „Krytyka bogini nie dotyczy samych zmysłów, lecz szkodliwego na nie wpływu é $\theta o \varsigma$, «przyzwyczajenia»”. Zob. K. Mrówka, dz. cyt., s. 197. Podobnego zdania jest Narecki: „Tym zaś, co prawdopodobnie odrzuca Bogini, są po prostu przyrodzone i tradycyjne źródła informacji, to znaczy wszystko, co się widzi, słyszy i o czym się mówi. Kiedy jednak górę bierze «rozum», eliminując tym samym zgubny wpływ ethosu, wtedy zapewne nabiera również znaczenia poznanie za pomocą zmysłów". Zob. K. Narecki, Logos we wczesnej myśli greckiej, RW KUL, Lublin 1999, s. 135.

69 Jak zauważa Passmore o Bradleyu: „His dialectic is the dialectic of Parmenides and Zeno rather than the dialectic of Hegel”. J. Passmore, A Hundred Years of Philosophy, Gerald Duckworth \& Co., London 1917, s. 59. 
swój idealistyczny monizm, podobnie jak Parmenides zdając sobie sprawę z niemożności odrzucenia świata zjawisk, zauważy:

Cokolwiek odrzuca się jako zjawisko, nie jest z tego powodu po prostu nie-bytem. Zjawisk nie można się tak po prostu gremialnie pozbyć, jakby zwalniając je z posady, a to dlatego, że skoro muszą gdzieś się przytrafiać, to i muszą należeć do rzeczywistości ${ }^{70}$.

Idealistyczna interpretacja myśli Parmenidesa wydaje się tłumaczyć, jak można uratować świat zmysłów w perspektywie eleackiej metafizyki. Bowiem w przeciwieństwie do materializmu, w ramach którego każda wielość implikuje jednocześnie podział i różnicę, idealizm godzi wielość $\mathrm{z}$ jednością $\mathrm{w}$ ten sposób, iż uznaje on partykularne przedmioty za pewne niesamoistne zjawiska będące przejawem jednego fundamentalnego Bytu. Jednak teza o idealizmie Eleaty może budzić wątpliwości części badaczy, którzy uważają ją za anachroniczną ${ }^{71}$. Niemniej wydaje się, że to, czy uznamy przypisywanie Eleacie materializmu bądź idealizmu za anachronizm, czy też nie, zależy od przyjmowanej przez nas metafizyki. Jeżeli bowiem uznamy, iż rzeczywiście istnieje coś takiego jak niematerialny byt, a samo wnioskowanie Parmenidesa jest poprawne, to problem rozwiązuje się sam, gdyż Eleatę możemy uznać za kogoś, kto odkrywa obiektywnie istniejącą rzeczywistość. Prawdą jest oczywiście, że on sam nie mówi wprost, iż byt jest niematerialny, gdyż (co zauważa wielu egzegetów myśli Eleaty) nie dysponował on jeszcze odpowiednim zapleczem terminologicznym ${ }^{72}$. Zarzut anachroniczności w tym wypadku staje się zatem dyskusyjny, tak jak dyskusyjne byłoby zarzucanie anachronizmu tym, którzy mówią o Krzysztofie Kolumbie jako odkrywcy Ameryki, mimo że termin „Ameryka” nie istniał w jego czasach, a sam żeglarz nawet nie zdawał sobie sprawy ze swego odkrycia. Tak jak Parmenides nie potrzebował

F.H. Bradley, Zjawisko a rzeczywistość, tłum. J. Szymura, Comer, Toruń 1996, s. 130.

71 Mourelatos uznaje Parmenidesa za antydualistę typów. Jednocześnie zaznacza, że nie chce przez to powiedzieć, że Parmenides był materialistą czy też idealistą. Zob. Mourelatos, dz. cyt., 130133: „In short, Parmenides argues for monism in the sense in which we speak of idealists or materialists as monists (I am not saying, of course, that he should be classified under either of these two schools; I cite them only as examples)".

72 Kahn wprost pisze, że do czasów Parmenidesa nie istniała ontologia, a co za tym idzie Eleata musiał operować na języku nieprzystosowanym do wyrażenia nowych metafizycznych myśli, przez co powinno się go rozumieć w ,jego własnych terminach”. Zob. Ch.H. Kahn, dz. cyt., s. 169. 
terminu „niematerialny”, tak tė̇ włoski żeglarz bez znajomości terminu „Ameryka" odkrył nowy kontynent ${ }^{73}$.

\section{Zakończenie}

Nie wydaje się zatem przesadą przypisanie Parmenidesowi, czy też całej szkole elejskiej, stanowiska idealistycznego ${ }^{74}$, szczególnie, iż wydaje się ono niejako dopełnieniem i konsekwencją jego monizmu numerycznego. Zdaje się, że właśnie tylko taka interpretacja, tj. monistyczno-idealistyczna, jest zgodna zarówno z treścią poematu Eleaty, jak i z późniejszą jego recepcją. Jak widzieliśmy, by obronić stanowisko, zgodnie z którym Eleata przyjmował pluralizm ontologiczny (gdyż w rzeczywistości monizm predykatywny jest pluralizmem), zmuszeni jesteśmy uznać, że żaden ze starożytnych filozofów, prócz niektórych presokratyków, nie zrozumiał myśli Parmenidesa. Ponadto zgodnie z tezami Curd i Kuboka, Anaksagorasa, Empedoklesa i Platona powinniśmy uznać za eleatów, a z kolei Zenona i Melissosa - nie.

Eleacka rewolucja na zawsze zmieniła oblicze zachodniej filozofii, gdyż po raz pierwszy w jej historii rozum staje się jedynym prawomocnym narzędziem poznania, a jego metodą - dedukcja. Rozważania wcześniejszych filozofów były oparte na nieoczywistych założeniach i prostej indukcji. Eleatyzm wprowadza nowy typ uprawiania filozofii i rozpoczyna poważną metafizyczną refleksję:

Do tej pory wszelkie myślenie filozoficzne miało charakter fizykalny - wychodziło od pytania o stałą podstawę procesów powstawania i ginięcia, o źródło

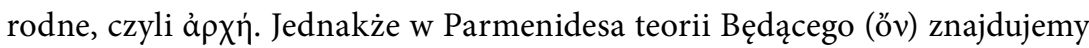
nowy i oryginalny punkt wyjścia ${ }^{75}$.

\footnotetext{
73 Warto w tym miejscu zauważyć, że nie dość, iż Parmenides do odkrycia tego, co niematerialne, nie potrzebował terminu "nie-materialność, to podobnie jak Kolumb w przypadku swego odkrycia, Eleata nie musiałby zdawać sobie sprawy z odkrycia niematerialnej rzeczywistości, by ją rzeczywiście odkryć. Znamienne jest też to, że Eleata opisuje Byt głównie w sposób negatywny (tj. niezrodzony, niezniszczalny, niewzruszony, niepodzielny), tak jakby był on opisywany w opozycji do tego, jak to-co-jest jest postrzegane przez „dwugłowych śmiertelnych”.

74 Za idealistę Parmenidesa uważał m.in. Hegel. Zob. G.W.F. Hegel, Wykłady $z$ historii filozofii, tłum. S.F. Nowicki, t. I, Wydawnictwo Naukowe PWN, Warszawa 1994, s. 354-355.

75 W. Jaeger, Teologia wczesnych filozofów greckich, tłum. J. Wocial, Homini, Kraków 2007, s. 151.
} 


\section{Bibliografia:}

Albert K., O platońskim pojęciu filozofii, tłum. J. Drewnowski, Wydawnictwo IFiS PAN, Warszawa 1991.

Arystoteles, Fizyka, tłum. K. Leśniak, PWN, Warszawa 1968.

Arystoteles, O powstawaniu i ginięciu, tłum. L. Regner, PWN, Warszawa 1981.

Barnes J., The Presocratic Philosophers, Routledge, London 2005.

Barnes J., The Presocratic Philosophers, Routledge, London 1982.

Bergson H., Dwa źródła moralności religii, tłum. P. Kostyło, Znak, Kraków 1993.

Blandzi S., Między aletejologia Parmenidesa a ontologią Filona, Wydawnictwo

IFIS PAN, Warszawa 2013.

Bradley F.H., Zjawisko a rzeczywistość, tłum. J. Szymura, Comer, Toruń 1996.

Burnet J., Early Greek philosophy, Adam and Charles Black, London 1908.

Cornford F.M., Plato and Parmenides, Kegan Paul, Trench, Trübner \& Co. Ltd., London 1939.

Coxon A.H., The Fragments of Parmenides, Van Gorcum, Assen 1986.

Coxon A.H., The Fragments of Parmenides, Parmenides Publishing, Las Vegas 2009.

Curd P., The legacy of Parmenides, Princeton University Press, Princeton 1998.

Drozdek A., Życie jest snem Bytu, „Analiza i Egzystencja” 2011, nr 13, s. 5-11.

Dunham J. i in., Idealism, Routledge, London, New York 2011.

Gadamer H.G., Początek filozofii, Wydawnictwo, tłum. J. Gajda-Krynicka, IFIS PAN, Warszawa 2008.

Gallop D., Parmenides of Elea, University of Toronto Press, Toronto, Buffalo, London 1991.

Guthrie W.K.C., A History of Greek Philosophy, t. II, Cambridge University Press, Cambridge 1969.

Hegel G.W.F., Wykłady z historii filozofii, t. I, tłum. Ś.F. Nowicki, Wydawnictwo Naukowe PWN, Warszawa 1994.

Henn M.J., Parmenides of Elea, Praeger, London 2003.

Jaeger W., Teologia wczesnych filozofów greckich, tłum. J. Wocial, Homini, Kraków 2007.

Kahn Ch.H., Being in Parmenides and Plato, w: tegoż, Essays on Being, Oxford University Press, New York 2009.

Kirk G.S. i in., Filozofia przedsokratejska, tłum. J. Lang, PWN, Warszawa 1999. 
Kubok D., Prawda i mniemania. Studium filozofii Parmenidesa $z$ Elei, Wydawnictwo Uniwersytetu Śląskiego, Katowice 2004.

Kubok D., Prawda i mniemania. Studium filozofii Parmenidesa $z$ Elei, Katowice 2004, rec. A. Pacewicz, „Roczniki Filozoficzne” 2006, nr 1(54), s. 266-275.

Mourelatos A.P.D., The Route of Parmenides, Parmenides Publishing, Las Vegas 2008.

Mrówka K., Heraklit, Scholar, Warszawa 2004.

Mrówka K., Parmenides. Ścieżka Prawdy, PWN, Warszawa 2012.

Narecki K., Logos we wczesnej myśli greckiej, RW KUL, Lublin 1999.

Owen G.E.L., Eleatic Questions, w: Logic, Science, and Dialectic, eds. M. Nussbaum, NCROL, London 1986.

Palmer J., Parmenides and Presocratic Philosophy, Oxford University Press, New York 2009.

Palmer J., Plato's Reception of Parmenides, Clarendon Press, Oxford 1999.

Passmore J., A Hundred Years of Philosophy, Gerald Duckworth \& Co., London 1917.

Phillips E.D., Parmenides on Thought and Being, „Philosophical Review” 1955, No. 4.

Platon, Państwo, tłum. W. Witwicki, Wydawnictwo Antyk, Kęty 2003.

Platon, Sofista, tłum. W. Witwicki, w: tegoż, Sofista, Polityk, Wydawnictwo Antyk, Kęty 2002.

Platon, List VII, tłum. M. Maykowska, w: tegoż, Listy, PWN, Warszawa 1987.

Plotyn, Enneady, t. II, tłum. A. Krokiewicz, PWN, Warszawa 1959.

Reale G., Historia filozofii starożytnej, t. I, tłum. E.I. Zieliński, KUL, Lublin 2008.

Tarán L., Parmenides. A text with translation, commentary and critical essays, Princeton University Press, Princeton 1965.

Uchan A., Zenon $z$ Elei i eleacki immaterializm, „Przegląd Filozoficzno-Literacki” (przyjęty do druku).

\section{Streszczenie}

Celem pracy jest analiza koncepcji bytu w filozofii eleatów. Szczególnej analizie poddane zostały poglądy wypracowane przez Parmenidesa $z$ Elei i opisane przez 
niego w heksametrycznym poemacie $O$ naturze. Filozofia eleacka budziła już od momentu swego powstania wiele kontrowersji, również dziś uczeni nie są zgodni co do interpretacji myśli tej szkoły. Dlatego też w pracy została podjęta próba odpowiedzi na pytanie: czy bytowi eleackiemu można przypisać niematerialność? Analizie poddano także interpretację monizmu predykatywnego zaproponowaną przez Patricię Curd.

Słowa kluczowe: Parmenides z Elei, Zenon z Elei, Melissos z Samos, monizm, filozofia eleacka, byt, bycie, idealizm

\section{Summary}

\section{The Problem of Interpreting Parmenides's Thought in the Spirit of Predicative and Numerical Monism}

The purpose of this study is to investigate the concept of being in the Eleatic philosophy. Special analysis has been devoted to the doctrine developed by Parmenides of Elea, in his poem On Nature. From its very beginning, the Eleatic philosophy has stirred controversy, even today's scholars are not unanimous in their interpretation of the school. Therefore, the research has been done to answer the question whether immateriality can be attributed to the Eleatic concept of being, and if predicative monism interpretation proposed by Patrica Curd is valid.

Key words: Parmenides of Elea, Zeno of Elea, Melissus of Samos, monism, Eleatic philosophy, being, idealism 